Historic, archived document

Do not assume content reflects current scientific knowledge, policies, or practices. 



\section{Plamt Trees}

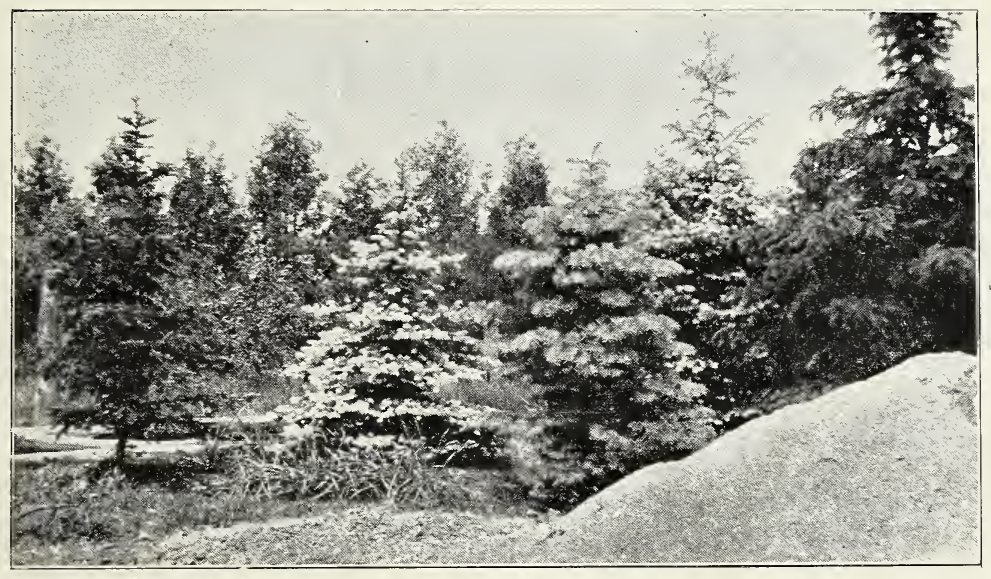

1923

$\mathbb{E} V \mathbb{E} R \mathbb{R E E N ~ N U R S E R Y ~}$

VAL KATZENBERGER, Manager FOSTERS, MICHIGAN. 


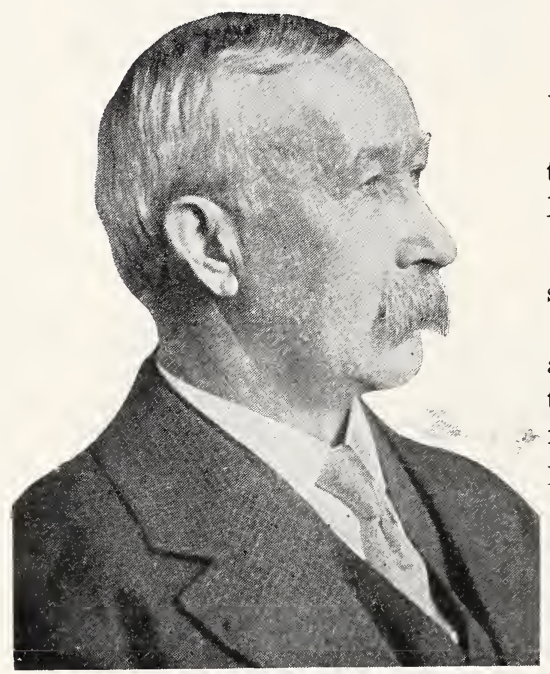

February 1st, 192:3

DEAR FRIEND:

Please permit me to present to you my 1923 Catalog and Price List.

I thank you for your generous support in the past, and beg that you may not withhold your patron. age in the future. I trust that our intercourse in the past has been of mutual benefit and hope that it may prove the same in the future.

Sincerely yours,

VAL KATZENBERGER

R. F. D. 2 Fosters, Mich.,

\section{TO THOSE WHO DON'T KNOW:}

My Nursery may be found two (2) miles north of Fosters, on the east side of section thirty (30), Township of Bridgeport, one mile east of Sheridan Road and about seven (7) miles south from the Tower Clock. POST OFFICE ADDRESS: As I am located on rural route No. 2 out of Fosters, all correspondence should be addressed that way.

TELEPHONE. Call Federal 894X1.

POSTAGE, EXPRESS OR FREIGHT CHARGES must be paid by the purchaser, if plants are to be shipped that way.

GUARANTEE: I guarantee to furnish live and healthy trees and plants, but cannot assume the responsibility that belongs to the purchaser. If plants and trees are not satisfactory when received, they must be returned and money paid for the same will be cheerfully refunded.

CAUTION: On receiving the plants examine the shipment. If they look good to you plant at once or heel them in, in a moist, shady place. If not satisfactory for any reason notify me, or return them, and if I can not furnish what you want I will refund your money without a question.

Causes of failure are varied and many times beyond my observation and control. 


\section{EVERGREENS}

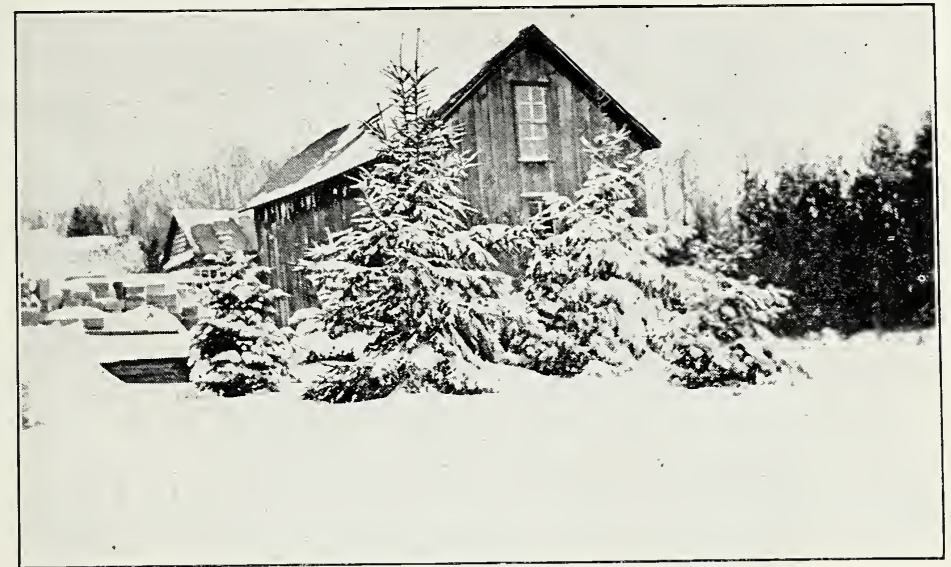

\section{NORWAY SPRUCE}

The Norway Spruce has been acclimated in this country so long that it may be classed as a native; it is hardy and will grow on a variety of soils. Like all the Spruces it is very popular and may be used as Specimen on the lawn or for Windbreak.

Specimen, $2 \frac{1}{2}$ to 3 feet, each …................................................. $\$ 1.00$

Specimen, 18 to 24 inches ..........

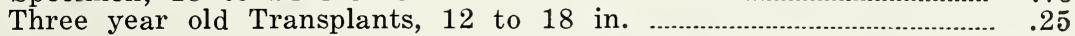

\section{WHITE SPRUCE}

A native of Michigan, has silvery gray foliage. Grows more compact with slender branches.

Specimen 18 to 24 inches, each.

$75 \mathrm{c}$

\section{AMERICAN ARBOR VITAE}

These Cedars are very useful as screens specimen on the lawn or formal hedges.

Specimen 6 to 8 feet with ball of earth and burlap. each...................\$5.00 3 -year Transplants, 15 to 18 inch

\section{ARBOR VITAE PYRAMIDALIS}

This highly ornamental variety is very popular; where a broad spreading tree would be out of place "Pyramidalis" coms into its own.

Specimen, 5-6 feet, each .............................................................. \$8.00

Specimen, 4-5 feet, each ……........................................................... \$5.00

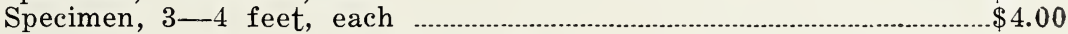

DWARF MOUNTAIN PINE-Where a low spreading evergreen is wanted the Dwarf Mountain Pine answers the purpose.

10 to 12 inches........ $\$ 1.25$

WHITE PINE, 3 year Transplants, 15 to 18 in.

PONDEROSA PINE, a native of Colorado with heavy spreading

branches, long dark green foliage. 3 feet, each. 
JACK PINE, a native of colder climates, will succeed on the dryest of hills.

The Jack Pine with its narrow upright growth and short foliage will places. withstand the heaviest storms, which fits it for windbreaks in bleak

$$
2 \text { feet........35c } 1 \text { foot........25c }
$$

IRISH JUNIPER, with its upright narrow growth and tense, steel green foliage makes a fine ornament for the lawn. 3 feet........\$3.00

WISCONSIN RED CEDAR, bluish green foliage, limbs wide spreading but set very symmetrically around the stem. 18 to 24 inches

HEMLOCK, specimen 18 inches high and as broad, bushy piants...... $\$ 1.50$

\section{DECIDUOUS SHADE TREES}

Norway Maple, 7-8 feet

Soft Maple, 12-14 feet

Ash Leafed Maple, 6 - 8 feet

American White Elm, 10-12

\section{TREES WITH PURPLE FOLIAGE}

Swedlery Maple, 6 - 7

Prunus Pissardi (purple-leaved plum)

\section{DOUBLE FLOWERING TREES}

Prunus Triloba, double flowers

Bechtel's Double Flowering Crab

\section{WEEPING TREES}

Campertown Elm, 2 year head

Catalpa Bungi, 2 year head

Teas Weeping Mulberry, 2 year

Wisconsin Weeping Willow, 8 feet

Cut Leaved Birch, $6-8$ feet

Weir's Cut Leaf Maple

\section{NUT BEARING TREES}

American Black Walnut, 8-10 feet

American Black Walnut, 6-8 feet

$\$ 1.00$

American Sweet Chestnut, 6 - 7 feet

$\$ 1.00$

Butternut, 1 year old, each .250

\section{PLANTING DIRECTIONS}

FIRST-Dig deep and wide; keep the good top soil on one side and the poor subsoil on the other.

SECOND-Fill in the hole enough of good soil, that if the plant is set thereon, the crown of the roots is slightly below the level of the ground, according to the size of the plant.

THIRD-Pack good soil around and under the roots-filling all empty spaces.

FOURTH-If the soil be dry, use water freely to moisten and further help pack the soil.

FIFTH-Fill in more soil and tamp.

SIXTH-Fill up with loose soil and level off.

It is needless to say that all mutilated roots should have been trimmed and straggling ones cut back, and the tops cut back to balance the proportion of the tops to the roots.

Aside from a good watering in dry weather-frequent loosening of the surface with the hoe, will be all that is necessary. 


\section{Elowering Shrubs}

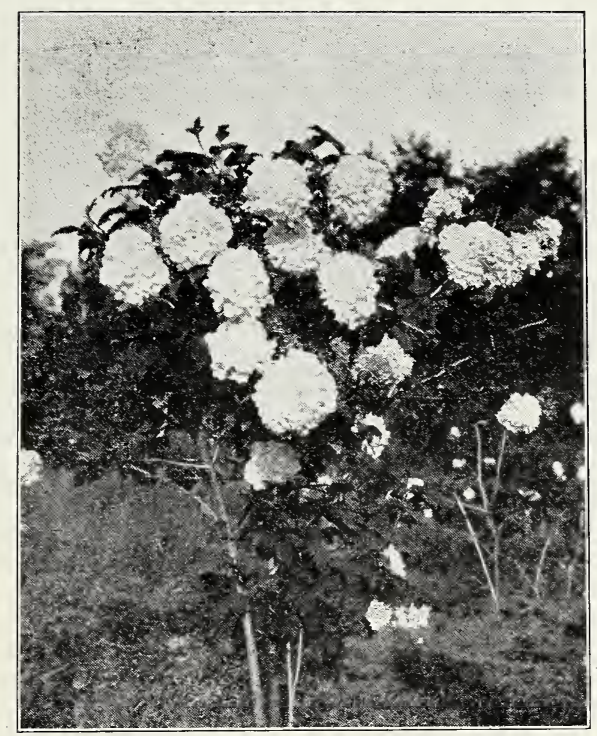

ALTHEA, also called Rose of Sharon, comes in a variety of colors, white, pink, red, blue and varigated, in single and double flowers, blossoms in Autumn.

Bush form, 18-24 inches, each

Tree form, 3-4 feet, each

ALMOND, double flowers, white and pink

BARBERRY THUNBERGI, the only safe hedge plant in that class, all others are barred.

18 inch, 3 year

$12-15$ inch, 2 years

1 year seedlings

FORSYTHEA, blooms in early spring before the leaves are out, blossoms yellow

HYDRANGEA, Grandiflora Paniculata bush

$.75 c$

HYDRANGEA, paniculata Tree form, 2 - 3 feet

HYDRANGEA, arborescens, Hills of Snow, flat panicles blooms in late summer

TARTARIAN BUSH HONEYSUCKLE, pink flowers $50 \mathrm{c}$

SNOWBERRY blooms late and is followed by snowwhite fruits, which are very ornamental until destroyed by heavy frosts..........50c

WAXBERRY, or Indian Currant, blossoms are not very showy, but the wax like berries which line the upper third of the branches are very pretty and persist way into winter

RODOTYPUS, or White Kerria, bright green corrugated foliage, white blossoms, followed by black berries, a very desirable shrub 
$: \quad:$

: :

FOSTERS, MICH.

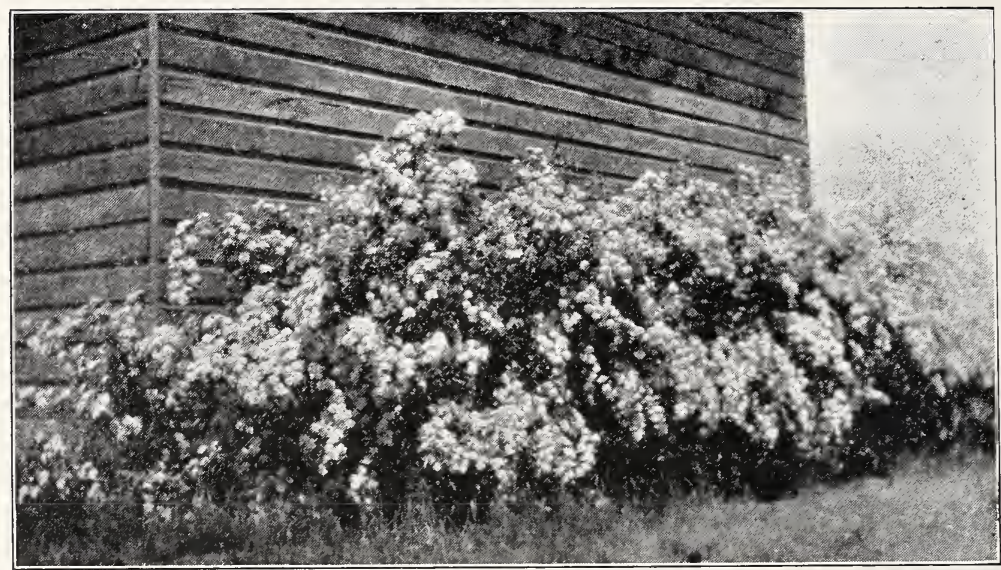

\section{Spired}

SPIREA VAN HOUTI, this shrub stands "ace high" in popular.

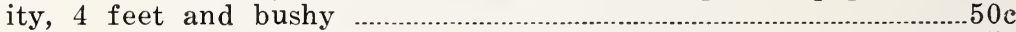
3 feet

SPIREA, ANTHONY WATERER, blooms pink in late summer, of dwarf habit

SPIREA PRUNIFOLIA (bridal wreath) of upright growth with double pink blossoms

SPIREA THUNBERGI, Fern leaf spirea, long very narrow foliage and white blossoms

PHILADELPHUS, Syringa Grandiflorus, 4 feet …................................50c

PHILADELPHUS, coronarius, sweet scented, 3 feet...........................50

PHILADELPHUS, Syringa Golden, golden yellow foliage of dwarf habit

PHILADELPHUS, Lemoine, narrow foliage, small white blossams......50e

SNOWBALL, Japan ............................................................................

WEIGELIA, rosea ..............................................................................................

WEIGELIA, Eva Radtke, red blossoms .................................................... 75 c

PRIVET, California, for hedges ….......................................................

PRIVET, Riegels flowering Privet, horizontal branches, will grow

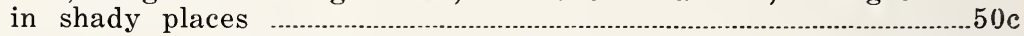

PRIVET, Amoor River Privet North, hardier than other kinds, each....50c CORCHORUS dwarf, varigated, silver leaf, double yellow blossoms in spring

\section{STATE DEPARTMENT OF AGRICULTURE CERTIFICATE OF NURSERY INSPECTION \\ No. 2555}

This is to Certify, that I have examined the nursery stock of Val. Katzenberger, Fosters, Michigan, and find it apparently free from dangerous insects and dangerously contagious tree and plant diseases.

This certificate to be void after July 31,1923 .

\section{Bureau of Foods and Standards,}

Lansing, Mich., September 16, 1922. W. P. HARTMAN, Director. 


\section{Roses.}

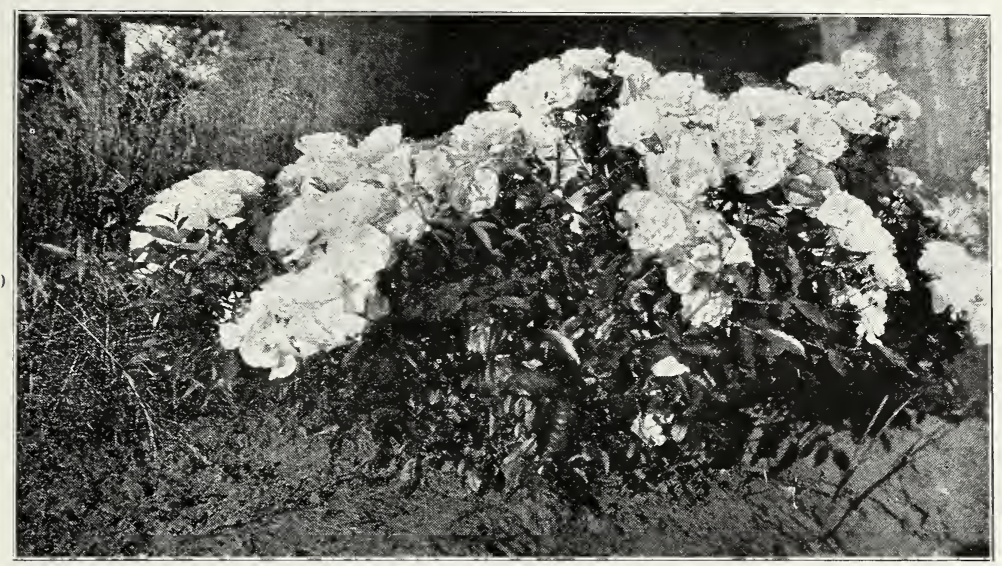

CRIMSON RAMBLER, a strong grower and free bloomer...................50c

DOROTHEA PERKINS, shell pink, very popular …............................50e

WHITE DOROTHEA PERKINS, the counterpart of the other ex-

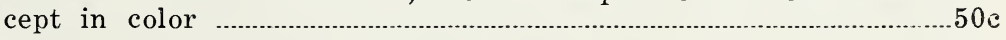

EXCELSA, or red Dorothea Perkins ................................................

CLIMBING BABY RAMBLER, a strong grower and free bloomer......50c CLIMBINS AMERICAN BEAUTY …...........................................................50c

POLYANTHA OR BABY ROSES, this class of roses bloom the entire season.

CRIMSON BABY RAMBLER, this is the old form of baby roses from which all the others originated $50 \mathrm{c}$

BABY DOROTHEA, pink Baby Rambler ….............................................50c

KATHERINE ZIEMET or White Baby Rambler, very fragrant............50c

BABY ELLEN PAULSON, pink splashed with crimson ........................50c

\section{Hybrid Perpetuals.}

AMERICAN BEAUTY, a great favorite ..................................................50

PAUL NEYRON, pink, very large ........................................................50

ULRICH BRUNNER, cherry red, thornless .............................................50c

FRAU CARL DRUSCHKE distinctive form and charming beauty........50c

HERMOSA, old but ever welcome ...................................................................50

GRUSS ON TEPLITZ, scarlet, constant bloomer ....................................50c

GEN. JAQUEMINOT, bright crimson .....................................................50c 


\section{Vines and Climbers}

AMPELOPSIS QUINQUEFOLINA, American Ivy $.50 \mathrm{c}$

AMPELOPSIS VEITCHI, Boston Ivy, will cling to brick wall with-

out other support $50 \mathrm{c}$

ARISTOLOCHIA, or Dutchman's Pipe, large overlapping foliage, making a dense shade

BIGNONIA, Trumpet Flower $.50 \mathrm{c}$

Celastris, Bittersweet scarlet berries, very ornamental $50 \mathrm{c}$

Wistaria, Chinese purple, long pendulous cluster of pale blue flowers

HALL'S JAPAN HONEYSUCKLE, cream white flowers, sweet scented $50 \mathrm{c}$

CLEMATIS JACKMANNI, purple flowers …………………………................50c

CLEMATIS HENRI, white flowers $.50 \mathrm{c}$

CLEMATIS PANICULATA, small starlike flowers, blooms in large masses in the Fall

\section{Hardy Perennials}

CHRYSANTHEMUM, the hardy pompon, white, yellow, and red, each $25 \mathrm{c}$

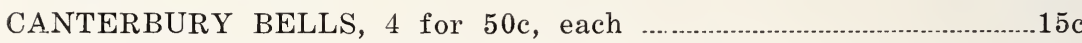

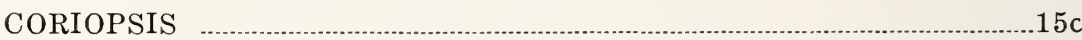

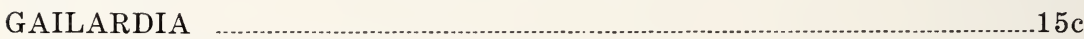

DELPHINIUM LARKSPUR ……................................................................15 c

ORIENTAL POPPIES ..............................................................................15c

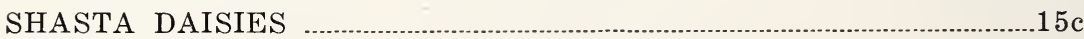

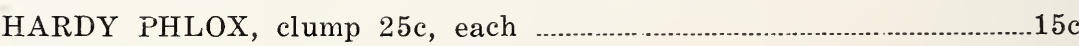

BRIDE'S MAID, white, red center

La MAHDI, velvety purple

R. P. STRUTHERS, cherry red

REINSTROM, rose pink, very large

CLAREMOND, silvery pink

MRS. JENKINS, tall white, large panickles

Mixed Lots, 10c each; 50c per 6.

IRIS, purple, blue, yellow, red, white and lavender...............................15c

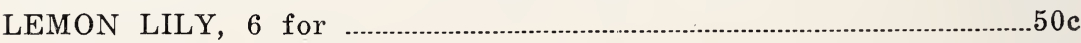

LILY OF THE VALLEY, large clump ......................................................50c

BLEEDING HEART, division, each ..........................................................5nc

BLUE MYRTLE for ground cover, 12 for ......................................\$1.00 
CREEPING PHLOX or MOSS PINK, clump $50 \mathrm{c}$

YUCCA FILAMENTOSA, Adams Needle, each $50 \mathrm{c}$

SPIREA PALMETTA, pink plumes, 7 to 10 inches in length on 4 foot stems, each $50 \mathrm{c}$

NEW ENGLAND ASTER, masses of small purple blossoms on in late Fall, each

\section{Peonea}

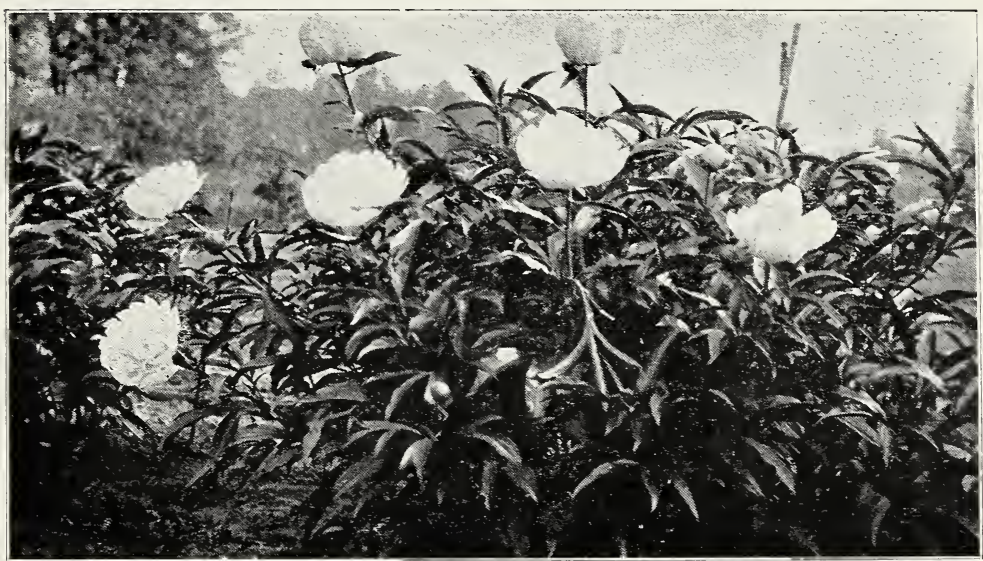

PEONIES-Divisions Three to Five Eyes. $.50 \mathrm{c}$

FESTIVA MAXIMA, an early white

COURONA DE OR, late white

Several shades of pink, small clumps, each

Large Clumps, per stem …..........................................................................10

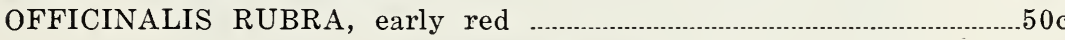

\section{Gladoili}

$8 c$ each; $75 c$ per twelve

MOUNTAIN ROSE, soft pink

INDEPENDENCE, rosy pink

PINK BEAUTY, soft pink, ruby throat, very early

HALLEY, delicate salmon pink, early

EVELYN KIRTLAND, tall stately, color from shell pink at the center to rosy pink at the edges with ruby blotches on the lower petals. MRS. FRANCIS KING, large spikes of showy flowers, pure light scarlet Mixed Lots of Common Kinds, $\$ 1.00$ per 100 


\section{Gladoili-Choice Varieties.}

10c each; $\$ 1.00$ per twelve

MRS. FRANK PENDLETON, flowers large, well expanded, salmon pink, dark red blotch on lower petals

BARON HULOT, deep Indigo blue

SCHWABEN, pure canary yellow, goiden yellow throat, blooms are closely set on strong tall stems

AMERICA, soft flesh pink.

PANAMA, deeper pink and somewhat larger than America

PRINCEPINE, scarlet with white blotch at the throat, showing more open blooms than Princeps

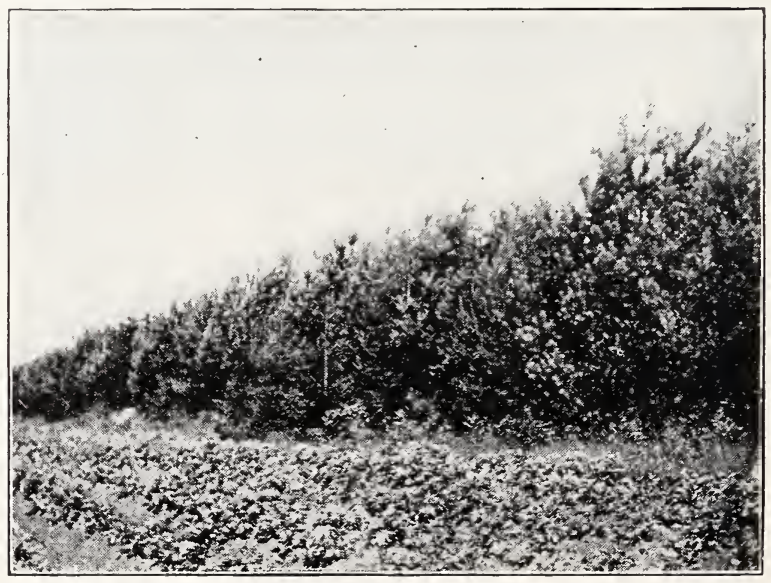

A Serviceable Windbreak 


\title{
STRA WBERRIES
}

\author{
$\$ 6.00$ per 1,000; $\$ 1.00$ per 100
}

In Strawberry growing, soil, location, and care form the tripod of success.

SOIL-Any land that will grow a maximum crop of corn or potatoes will also grow strawberries, if the other factors are right.

LOCATION-Low, swampy ground, or dry knolls should be avoided, as Jack Frost will get your berries on the one and drouth on the other.

CARE-Choose a rich piece of ground that has been cultivated for several years and is clear of sods or weeds. Plant early in spring in rows 24 to 30 inches apart for hand culture, or from 3 to $3 \frac{1}{2}$ feet for field culture, wth plants from 12 to 18 inches apart in the row; however, plant close to let the rows fill up with plants early in the season. Keep the ground well cultivated and free from weeds, and later, when the rows are well filled with plants, cut away all surplus runners.

At the approach of cold weather, place a clean mulch between the rows, and after the ground is frozen, over the rows as well. In the spring, if your mulch is thick on the plants remove a part, so that the plants may be able to grow up through, but leave that between the rows, it will keep the ground from drying out, keep out weeds and also keep your berries clean.

\section{SENATOR DUNLAP}

This strawberry is so well known that it needs no introduction. It is the standard for quality both for the table and canning. Blossoms are perfect, fruit dark red and firm.

\section{GIBSON AND GLEN MARY}

These two varieties have perfect blossoms and produce large quantities of bright colored berries in quality much above the average.

\section{BRANDYWINE}

Judging from the demand for this variety it must have some virtue above others. I have never been able to supply the demand for Brandywine berry plants. It is large, firm, dark red and late in ripening. It requires rich soil and good care.

\section{GANDY}

A late berry with perfect blossoms. Plant is healthy and free from rust; ripens its fruit to the last; grows and thrives on heavy moist soil.

\section{KELLOG'S PRIDE OF MICHIGAN}

Like Gandy and Brandywine this berry is late in ripening, prolonging the strawberry season from 10 days to two weeks. Blossoms perfect, foliage healthy and production of large berries.

\section{PREMIER}

$\$ 1.00$ per Hundred

A new introduction, said to be an early berry without a fault. 
DR. BURRILL

$\$ 1.00$ per Hundred

Said to be an improved Dunlap, a cross between that variety and Crescent, with all the good qualities of its parents and none of their faults.

\section{FALL BEARING STRAWBERRIES PROGRESSIVE}

This is a fall bearing or better said an everbearing strawberry.

Some growers have great success with this berry, but it requires very rich soil and the best of care.

\section{RASPBERRIES \\ CUTHBERT OR QUEEN OF THE MARKET} hundred.

This is a standard variety and is well known. 50s per 12; $\$ 3.00$ per

\section{ST. REGIS}

A bright red berry of the Cuthbert type and quality, bearing two crops of berries the season, planted one on the old wood in July and another on the new wood in the fall; unlike as with everbearing strawberries, St. Regis requires no extra manipulation to produce the berries. $\$ 1.00$ per 12: $\$ 5.00$ per 100 .

\section{COLUMBIAN PURPLE CAP}

A plant of large growth, hardy and productive, bearing great crops of purple berries of large size and fine quality. The plant does not sucker like some of the red varieties, but increases from tip grown plants; for that reason plants are scarce and high in price.

\section{$\$ 1.00$ per 12: $\$ 5.00$ per 100 \\ CUMBERLAND BLACK CAP}

The largest Black Raspberry known. The plants are strong and healthy, hardy and productive. The berries are firm, yet juicy and good. 50c per 12; $\$ 300$ per 100 .

\section{LUCRETIA DEWBERRIES-\$1.00 per 12 \\ BLACKBERRIES}

"Snyder" is a dependable kind and the only one I recommend. It is hardy and productive. 50c per 12; \$2.50 per 100. 


\section{GRAPES}

\section{CONCORD}

The standard grape for a large part of the country.

Each 25c; Twelve, \$2.75; Per Hundred \$20.00

WORDEN

A better grape for the family fruit garden at the same price.

MOORE'S EARLY

Fully two weeks earlier than Concord; fine for early and nearby markets.

25c Each; \$2.75 Pex Twelve

CAMPBELL.'S EARLY

A large grape, long shouldered bunches with long keeping qualities.

40c Each; \$2.00 Per Six

\section{CLINTON}

A small black grape, very hardy and productive.

25c Each; $\$ 2.50$ per Twelve BRIGHTON

A red grape, medium bunch and berries.

30c Each; $\$ 3.00$ per Twelve

\section{LUCILLA}

A fine red grape, very productive. Bunches and berries large-30c each

AGAWAM

Large, spicy, finest quality red grape-25c Each; $\$ 2.50$ per Twelve

NIAGARA

The standard white grape, bunches and berries large.

25c Each; $\$ 2.75$ per Twelve; $\$ 20.00$ per Hundred

MOORE'S DIAMOND

An early white grape somewhat smaller than Niagara. sweet and good.

30c Each: $\$ 3.00$ per Twelve

\section{ELVIRA}

A fine show grape, branches medium, very compact

25c Each; $\$ 2.50$ per Twelve 


\section{Fruit Trees}

I will be able to supply my customers with a limited quantity of fruit trees.

APPLES, at 75c Each-In the following varieties

Transparent, Astrachan, Oldenburg, Golden Sweet, Wealthy, Snow, Grimes Golden, Wagner, Spy, Transcendent Crab.

$$
\text { DWARF APPLES—75c Each }
$$

Yellow Transparent, Wealthy, Wagner

STANDARD PEARS- $\$ 1.00$ Each

Clapp's Favorite, Sheldon, Anjou

DWARF PEARS-75c Each

Bartlett, Anjou and Duchess Ang.

PLUMS- $\$ 1.00$ Each

Lombard, Burbank, Shippers Pride and German Prune

CHERRIES- $\$ 1.00$ Each

Early Richmond, Montmorency, English Morrillo, Windsor

ASPARAGUS

Palmetto Selected Roots

$\$ 1.25$ per Fifty; $\$ 2.00$ per Hundred

RHUBARB-Whole clumps, 25c Each; divided roots, 15c Each 


\section{S P R A Y I N G}

You may have the finest orchard on the highest priced land; you may cultivate and prune; but the countersign to success is SPRAY. One very big drawback in the past has been the great number of insect and fungus enemies, as well as the great number of remedies to be applied for each. Of late years the discovery has been made that the lime sulphur solution will kill the spores of blight, as well as scale insects, by contact, and if we add a little arsenate of lead we also kill insects that chew, as well as the apple worm.

If we arrange for the spraying in a systematic manner-three or four sprays a year-we will save the orchard and protect the fruit.

FIRST SPRAY-After the leaves have fallen in the fall,but before the buds open in the spring, take five gallons of concentrated lime sulphure solution to from 40 to 45 gallons of water; cover the tree from both sides, the large branches as well as the body of the tree. This so-called dormant spray will have killed the eggs of the tent caterpillar, the eggs of the green fly (Aphis), oyster-shell bark louse, and above all things else the San Jose scale, besides the spore of the blight and other fungi that it has come in contact with. This may be applied to all trees, shrubs and vines and even on some evergreens.

SECOND SPRAY - Spray after the petals have fallen, for the Codling moth and other insects that may have escaped the winter spray; also for the curculio and possible spores of blight. Remedy: One gallon lime sulphur solution to 50 gallons of water and two pounds of arsenate of lead.

THIRD SPRAY - Ten days after, repeat on apples, pears and plums. At this time use half a pound of arsenate of lead to $12 \frac{1 / 2}{2}$ gallons of water.

FOURTH SPRAY-Spray about July 25 th on all the late apples, one pound of arsenate of lead to 25 gallons of water. The time for this spray may vary with the season.

FOR CURRANT WORM-As soon as the worm appears spray with arsenate of lead; one ounce to three gallons of water. If the worms trouble later spray with white helebore; one ounce to three gallons of water.

FOR CURCULIO ON PLUM-Spray with arsenate of lead; onequarter pound to twelve gallons of water.

FOR SLUGS AND APHIS ON ROSES AND HOUSEPLANTSSpray with a solution of Sulpho Tobacco Soap; 3 ounces to $1 \frac{1}{2}$ gallons of water.

FOR ROT ON GRAPE AND SCAB ON TREE FRUITS-Spray with a solution of copper sulphite or blue stone; 1 ounce to $1 \frac{1}{2}$ gallons of water. 


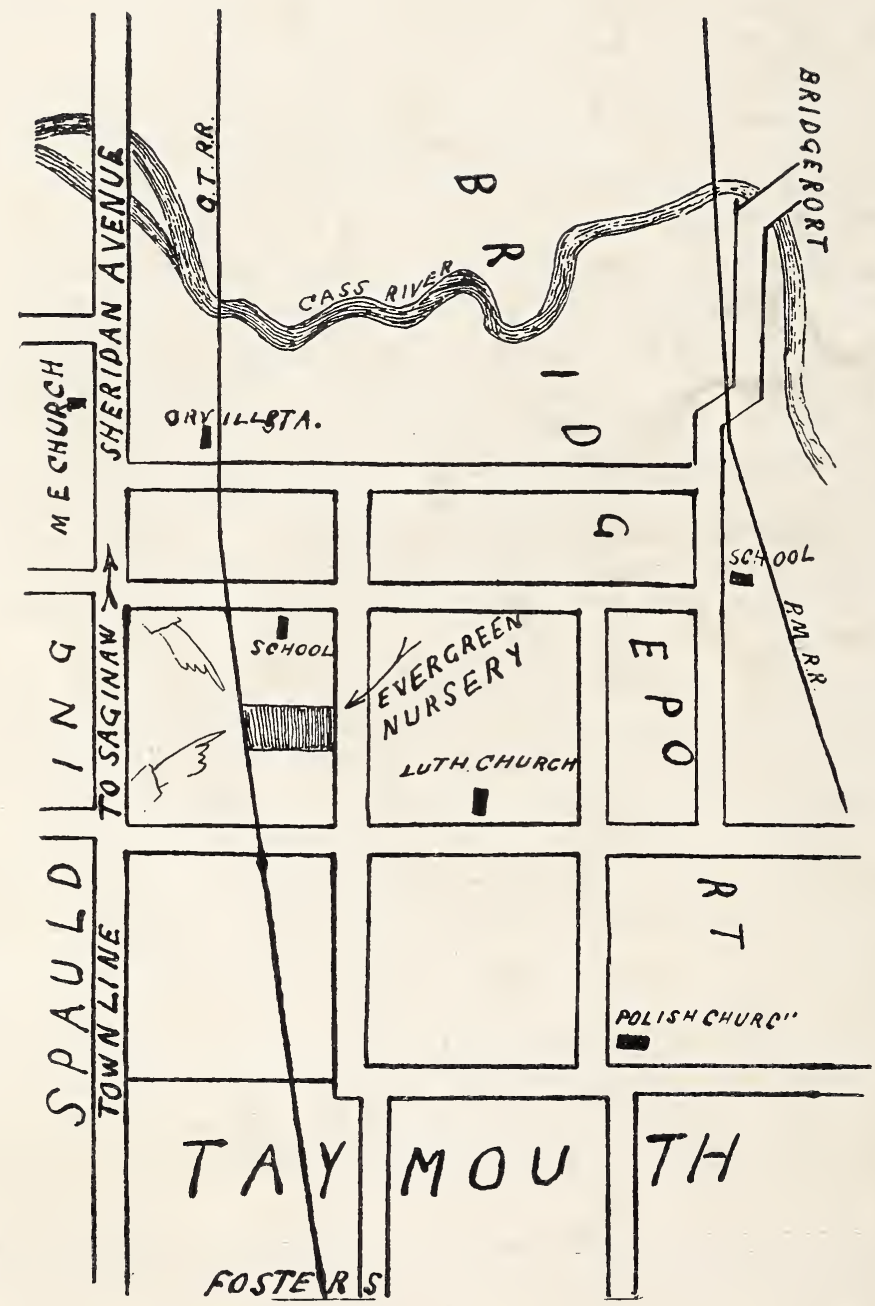

